\title{
Na tropach tajemniczego M.K.
}

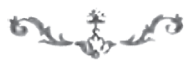

$\mathrm{P}$ ONIŻSZY TEKST PUBLICYSTYCZNY, wydobyty na światło dzienne ze szpalt zapomnianego i efemerycznego tygodnika, jakim był wychodzący w Warszawie w latach 1896-1898 „Kurier Niedzielny”, nie zaleca się specjalnymi walorami treściowymi czy formalnymi. Wydaje się intrygujący głównie z jednego powodu - niejasnego autorstwa, ukrytego pod inicjałami M.K. Na historyków literatury polskiej drugiej połowy XIX wieku muszą one działać alarmująco, sugerują bowiem pierwszorzędne pióro Marii Konopnickiej. Czyżbyśmy mieli do czynienia z nieznanym tekstem znamienitej poetki i nowelistki? W takim razie banalny artykuł, poświęcony nadużywaniu pejoratywnego terminu „filister” oraz przesadnej samoocenie elit artystycznych, zyskiwałby od razu na randze i znaczeniu. Czy jednak taki sposób odczytania inicjałów jest poprawny? Niestety, w świetle dostępnych faktów jednoznaczna odpowiedź jest niemożliwa, dlatego niniejszy komentarz ma jedynie charakter wstępnego rekonesansu, nie ostatecznego rozstrzygnięcia ${ }^{1}$.

Tygodnik „Kurier Niedzielny”, określony może zbyt lekceważąco jako „magazyn o charakterze popularyzatorskim i rozrywkowym” ${ }^{2}$, ukazywał się

1 Bardzo dziękuję za szereg cennych spostrzeżeń, komentarzy oraz informacji - odwołuję się do nich w przypisach - osobom, u których zasięgałam rady w kwestii analizowanego tekstu: Pani Doktor Magdalenie Rudkowskiej, Pani Profesor Jolancie Sztachelskiej, Pani Doktor Lenie Magnone, Panu Profesorowi Tadeuszowi Budrewiczowi oraz Panu Dyrektorowi Muzeum Marii Konopnickiej w Żarnowcu, Pawłowi Bukowskiemu.

2 Tak uważa Mirosława Puchalska (zob. W. Kosiakiewicz, Widmo i inne opowiadania, wstęp M. Puchalska, Warszawa 1974, s. 9). Tygodnika „Kurier Niedzielny” nie 
od 4 października 1896 do 25 września 1898 roku (kolejno: 32, 52 i 39 numerów rocznie), wydawany przez Marię Chełmońską i „pod redakcją literacką Ludomira Grendyszyńskiego" " Zajmując pojednawcze stanowisko światopoglądowo-estetyczne, między wiernością tradycji a otwarciem na nowoczesność, deklarował przede wszystkim ambicje literackie (beletrystyczne) i artystyczne ${ }^{4}$. Cierpiąc na brak wyrazistej strategii wydawniczej tudzież wartościowszych materiałów ${ }^{5}$, nie zaprezentował jednak specjalnie interesującej oferty. Na odnotowanie zasługują niektóre solidniejsze artykuły ${ }^{6}$,

uwzględniają monografie Zenona Kmiecika (Prasa polska w latach 1864-1918, Warszawa 1976; Czasopisma warszawskie w latach 1886-1904, Wrocław 1989) czy Jerzego Jarowieckiego (Prasa na ziemiach polskich XIX i XX wieku, Wrocław 2013) - tytuł pojawia się kontekstualnie lub w adresach bibliograficznych.

3 Żyący w latach 1859-1922 prawnik, płodny literat i przedsiębiorczy redaktor, zapamiętany został głównie jako działacz społeczno-polityczny (Stronnictwo Realistów) i znawca kwestii gospodarczych, mimo swojej wieloletniej aktywności publicystycznej w „Kurierze Codziennym”, „Kraju”, „Kurierze Niedzielnym”, „Kurierze Polskim”, „Niwie”, „Słowie” i „Świecie” (zob. Polski Słownik Biograficzny, red. W. Konopczyński [i in.], t. 8, Wrocław 1959-1960, s. 575-576; dalej skrót: PSB). Gdy pod koniec 1897 roku Grendyszyńskiego zastąpił Stanisław Kijeński (odtąd adnotacja: „czasopismo tygodniowe, ilustrowane”), zawartość numerów stopniowo traciła na wartości; w dodatku rocznik 1898 zdominował Mickiewiczowski jubileusz. Po zawieszeniu „Kuriera Niedzielnego” w jego miejsce pojawił się „Tygodnik Polski”, wydawany przez Mariana Gawalewicza, o żywocie jeszcze krótszym. Dalej czasopismo oznaczam skrótem KN. „[...] rozpoczynając wydawnictwo nowego czasopisma tygodniowego, pragniemy je poświęcić literaturze, sztuce i popularyzacji wiedzy. [...] jest - sądzimy - miejsce dla pisma, które literaturze przeważnie i przede wszystkim służyć zamierza”; „Nie pogrążyliśmy się w literaturze akademickiej lub w wyrafinowanym estetyzmie. [...] bronimy przykazań pozostawionych nam tradycją pradziadów, otwierając jednak szeroki przystęp świeżym prądom - o ile wnoszą udoskonalanie dobrych, a wykorzenianie złych zasad" (KN 1896, nr 1, s. 1; 1897, nr 39, s. 458).

5 Bardziej znani autorzy, goszczący na łamach pisma, to: Kajetan Abgarowicz (Abgar Sołtan), Edmund Bogdanowicz (Bożydar), Władysław Bukowiński (Selim), Adolf Dygasiński, Henryk Galle, Marian Gawalewicz, Wojciech Gerson, Kazimierz Gliński, Zygmunt Gloger, Wiktor Gomulicki, Ferdynand Hoesick, Czesław Jankowski, Józef Jankowski, Wacław Karczewski (Marian Jasieńczyk), Jan Karłowicz, Kazimierz Kaszewski, Maria Konopnicka, Wincenty Kosiakiewicz, Stanisław Kozłowski, Stefan Krzywoszewski, Antoni Lange, Julian Łętowski, Jan Łoś i Wincenty Łoś, Ignacy Maciejowski (Sewer), Leopold Méyet, Władysław Nawrocki, Jan Nitowski, Artur Oppman (Or-Ot), Antoni Pilecki, Adam Pług, Zenon Przesmycki (Miriam), Maria Przewóska, Stanisław Rossowski, Leon Rygier, Edward Słoński, Klemens Junosza-Szaniawski, Kazimierz Tetmajer, Cecylia Walewska, Józef Waśniewski, Włodzimierz Zagórski.

6 Omówienia Faraona Prusa i Formy w poezji Włodzimierza Zagórskiego (Władysław Bukowiński), prezentacja sylwetki i twórczości Edmunda Rostanda (Roman Plenkiewicz), portret wybitnego językoznawcy Lucjana Malinowskiego (Hieronim 
ankieta na temat powieści, omówienia i przekłady literatur obcych, a także wstępne szkice Grendyszyńskiego i Stanisława Hłaski, wyróżniające się niejaką oryginalnością i temperamentem polemicznym. Poniższy tekst również można zaliczyć do tej grupy.

Szkic Artyści i filistry został opublikowany w numerze 10. (23 lutego/ 7 marca) z 1897 roku, na stronie tytułowej, gdzie zwykle w pierwszej połowie okresu istnienia czasopisma ukazywała się Kronika literacka Grendyszyńskiego. Nie był to jedyny tekst wstępny sygnowany kryptonimem czy pseudonimem, ale żaden $\mathrm{z}$ kilkunastu takich przypadków (poza analizowanym tylko trzy nastręczają wątpliwości w rozstrzygnięciu autorstwa) nie dotyczył ważniejszego tematu ${ }^{7}$. Casus M.K. rysuje się zatem dość wyjątkowo - skąd przy publikacji, omawiającej problem dość istotny w owym czasie, intencja zaszyfrowania autorstwa? Nasuwają się dwa przypuszczenia: albo znany autor $\mathrm{z}$ jakichś względów wolał pozostać anonimowy, albo inicjały kryją osobę zbyt mało znaną, by eksponować jej nazwisko.

\section{CZYŻBY KONOPNICKA?}

Istnieją trzy przesłanki okołotekstowe, które mogłyby przemawiać za autorstwem Marii Konopnickiej i które dokumentują jej związki z tygodnikiem. Pierwsza to podanie nazwiska poetki w programowej zapowiedzi redakcyjnej (KN 1896, nr 1 z 22 września/ 4 października, s. 2: „współpracownictwo zaś swe przyrzekli nam dotychczas [...] Konopnicka Maria [...]”). Druga przesłanka jest zarówno pozytywna, jak i negatywna, ponieważ rzeczone „Współpracownictwo” mogło się ograniczyć do pojedynczego precedensu: w tym samym roku co Artyści i filistry ukazał się już wiersz Konopnickiej podpisany pełnym imieniem i nazwiskiem - Modlitwa pieśniarza (KN 1897, nr 2 z 29 grudnia 1896/ 9 stycznia). I tym razem przypadło mu miejsce uprzywilejowane, tuż za wstępną Kroniką literacką redaktora Grendyszyńskiego. Trzecia poszlaka to ślad dłuższego (stałego?) zainteresowania pisarki warszawskim tygodnikiem: w zbiorach Muzeum Marii Konopnickiej w Żarnowcu zachowała się „Korrenspondenz-Karte” (nr inw. MKŻ/AH/210) z dnia 29 września 1897 roku o następującej treści: „Szanowną Administrację «Kuriera Niedzielnego» uprzejmie proszę o nadsyłanie mi swego pisma do Wiednia: Strozzi-gasse N 8. II Stiege I Stock. Z poważaniem M. Konop-

Łopaciński), szkic Pamiątki po Mickiewiczu w Wilnie (Leon Uziębło), etnograficzne studia Zygmunta Glogera (Nasze rzeki, W dolinie Biebrzy).

7 Były to np. przyczynki jubileuszowe, wspomnienia pośmiertne lub wypowiedzi okolicznościowe. 
nicka” ${ }^{8}$. Nieco zaskakujące kontakty z pismem „ugodowców” tłumaczy może sympatia do Grendyszyńskiego, kolegi pierworodnego syna poetki (zmarłego nieszczęśliwie $\mathrm{w} 1891 \mathrm{roku})^{9}$. Wiedeński pobyt podróżującej ustawicznie pisarki miał trwać ponad rok, a wcześniej przebywała we Lwowie (od jesieni do 10 grudnia 1896), Nicei (do marca 1897) i Monachium (kwiecień 1897), jak zwykle borykając się z kłopotami finansowymi - a ponieważ często produkowała teksty na zamówienie lub w celach zarobkowych, mogła w ten sposób napisać także Artystów i filistrów; artykuł musiałby powstać najpóźniej w okresie nicejskim ${ }^{10}$.

Na autorstwo Konopnickiej zdaje się wskazywać charakter niektórych sądów wyrażonych w tekście. To przede wszystkim wyraźny punkt widzenia pokolenia starszego niż generacja modernistów („nasi młodzi”), krytyczny osąd nietzscheańskiego „nadczłowieczeństwa”, etyczno-narodowe wezwanie do solidaryzmu artystów z ogółem i poszanowania rzetelnej pracy zwykłych „zjadaczy chleba” oraz postulat miłości jako najwyższego wyznacznika człowieczeństwa. To także przywołanie Fausta (wysoko cenionego przez pisarkę) i Heinricha Heinego (obficie tłumaczonego przez nią), dobre rozeznanie w sztukach plastycznych oraz dramaturgii, jak również inne przejawy orientacji (erudycji) literackiej, oczywiste u doświadczonej pisarki. Ciekawym, pośrednim dowodem może być wspomniany, autotematyczny wiersz Modlitwa pieśniarza, poświęcony właściwie tej samej problematyce: relacji artysty ze wspólnotą. Podmiot liryczny deklaruje rezygnację z natchnionej kondycji „orłów bożych”, „na harf królewskich [opartych] majestacie”, i wyrzeka się triumfalnego zwycięstwa w glorii sławy na rzecz najważniejszego celu twórczości: „Mnie tylko daj - te bratnie wzruszyć dusze” (1897, nr 2, s. 15). Wreszcie za piórem Konopnickiej mogłyby przemawiać pomniejsze elementy: odwołanie się do „butnej fantazji młodego jeszcze bądź co bądź narodu” polskiego czy topos złotego wieku kultury, „gdy artyści i lud przenikali się wzajemnie [...] w Grecji, w Atenach za Peryklesa, we Włoszech w czasie Odrodzenia” ${ }^{11}$.

8 Panu Dyrektorowi Pawłowi Bukowskiemu bardzo dziękuję za udostępnienie skanu korespondencji (wzmianka o kartce Konopnickiej znajduje się też w Nowym Korbucie).

9 „Żal mi, że ten Grendyszyński wlazł między tę ugodową hołotę, ze względu, że był kolegą Tadzia” - pisała do syna Jana w 1901 roku (M. Konopnicka, Listy do synów i córek, oprac. L. Magnone, Warszawa 2010, s. 632). Doktor Lenie Magnone bardzo dziękuję za zwrócenie uwagi na ten fakt.

10 Jakkolwiek na przełomie 1896/1897 Konopnicka miała kłopoty z pisaniem po oparzeniu ręki. Zob. T. Czapczyński, Tułacze lata Marii Konopnickiej. Przyczynki do biografii, Łódź 1957; M. Konopnicka, Listy do synów i córek..., s. 446, 455.

11 W szkicu Na ostrzu pióra. Pracownia („Biblioteka Warszawska” 1894, t. 4) o artyście 
Można się też sugerować nieco stylową, archaiczną fleksją słowa „filistry” w tytule tekstu - Konopnicka używała formy „modernisty” (por. niżej), podczas gdy u młodopolan można spotkać odmianę „filistrowie” ${ }^{12}$. To jednak ryzykowna przesłanka; uzus językowy był w owym czasie dość rozchwiany ${ }^{13}$.

Pozostaje kwestia stosowania przez Konopnicką kryptonimu M.K. Na podstawie wstępnej analizy można stwierdzić, że pisarka używała go w przypadku publikacji mniej cenzuralnych (głównie poza kordonem zaboru rosyjskiego) albo mniej znaczących. W prasie Kongresówki inicjałami podpisywała swe teksty (recenzje, artykuły, korespondencje, wiersze) głównie w latach 1881-1893; potem ta praktyka stała się nieco rzadsza. Kryptonimu M.K. użyła: w 1900 roku jako tłumaczka, w latach 1902-1903 i 1908 na łamach adresowanych do dzieci i młodzieży „Wieczorów Rodzinnych”, a w gorącym 1906 roku w prasie bieżącej chwili, „Narodzie”. W 1897 roku inicjały pojawiły się pod utworami literackimi zamieszczonymi w „Kurierze Przemyskim” ${ }^{14}$. Można nieco na wyrost wysnuć wniosek, że na przełomie wieków Konopnicka posługiwała się kryptonimem w przypadku publikacji mniej istotnych lub czasopism mniej znanych.

\section{DLACZEGO NIE KONOPNICKA?}

Jeżeli powyższe poszlaki są konieczne do uznania autorstwa Konopnickiej, to jednak nie są wystarczające. Poziom informacyjny i aksjologiczny tekstu jest na tyle ogólny, że może wskazywać na wielu użytkowników ówczesnej kultury, reprezentujących przyzwoitsze opanowanie liczącej się tradycji oraz ważniejszych kontekstów literackich, krajowych i zagranicznych. Pewną wskazówkę wnosi wyeksponowany w Artystach i filistrach wątek twórczości Henrika Ibsena, choć nie jest ona zbyt precyzyjna: potwierdza tylko dobre opanowanie przez autora języka niemieckiego oraz korzystanie z niemieckich książek. Znajomość Ibsena była u schyłku wieku oczywista - sławny i tłumaczony, głównie w obszarze niemieckojęzycznym, u nas znany był

szczerym, pełnym prostodusznego zapału i otwartym wobec ludzi pisarka mówi: „Jest on jeszcze Grekiem z czasów Peryklesa” (M. Konopnicka, Publicystyka literacka i społeczna, oprac. J. Baculewski, Warszawa 1968, s. 424).

12 Tak w korespondencji z Wiednia niejakiego Roberta Lewandowskiego (Modernizm w sztuce, $\mathrm{KN}$ 1897, nr 47, s. 587), który zdradza wyraźne inklinacje młodopolskie, opowiadając się po stronie „modernistów” przeciwko „filistrom” (i zaświadczając bezskuteczność apelu „M.K.”).

13 „Filistrzy/ filistry” pojawiają się i u Bogusławskiego, i u Gawalewicza (por. niżej).

14 Zob. Słownik pseudonimów pisarzy polskich, red. E. Jankowski, t. 2, Wrocław 1995, s. 548. 
przede wszystkim dzięki szkicom Georga Brandesa ${ }^{15}$. Także zestawienie bohaterów Ibsena i Goethego należało do popularnych, pisał o tym Władysław Bogusławski, autor wnikliwego studium o twórczości Norwega ${ }^{16}$. Wskazówki „terytorialne” również nie są jednoznaczne; autor szkicu dobrze orientował się zarówno w życiu kulturalnym Warszawy, jak Krakowa.

Przede wszystkim jednak nie wszystkie elementy tekstu korespondują $\mathrm{z}$ „profilem” Konopnickiej. Radykalne odcięcie się od pozytywistycznego minimalizmu przypomina raczej stanowisko młodopolan - a wcześniej postromantyków i niektórych przedstawicieli drugiego pokolenia pozytywistów („zaraza zmaterializowania i powolnego stężenia ducha”; „filisterstwo [...] z pięknego godła [pracy] wykroiło sobie wygodną sukienkę"). Zastanawia też sposób podejścia do kwestii modernizmu; jego wyraźne oceny pojawiają się w korespondencji Konopnickiej w latach 1899-1900 i są, jak wiadomo, surowe ${ }^{17}$. Czy poetkę w 1897 roku stać było na wyważoną konstatację, że „modernizm w literaturze” to nowość dezorientująca "masy”, odreagowujące wrogą lub szyderczą obojętnością? Wszak byłoby to wydanie na siebie niepochlebnego wyroku, który Konopnicka ferowała pod adresem modernistów. Tymczasem w uwadze autora tekstu Artyści i filistry, pełnej zrozumienia, ale i wyższości w stosunku do owych niepojętnych „mas”, pobrzmiewa raczej uznanie i sympatia dla nowych kierunków w sztuce. Wątpliwości także budzi dość bezkompromisowa rozprawa z pięknoduchostwem i wybraństwem

15 Duńczyk wielokrotnie pisał o Ibsenie w latach 1867-1899, np. w zbiorze szkiców Umysły współczesne. Portrety literackie, przeł. M. Posner-Garfein, t. 1-2, Warszawa 18931894 (Moderne Geister. Literarische Bildnisse aus dem neunzehnten Jahrhundert, 1887). Jego wczesne sądy o Ibsenie i Peer Gyncie, powtarzane też u nas, były negatywne (zob. H. Ibsen, Peer Gynt, tłum. Z. Krawczykowski, oprac. O. Dobijanka-Witczakowa, Wrocław 1967, s. LXXXII).

16 Bardzo prawdopodobne, że autor Artystów i filistrów inspirował się tekstami znanego krytyka. Bogusławski nie raz zestawiał (Kierkegaardowski według Brandesa) indywidualizm Ibsena $\mathrm{z}$ indywidualizmem Goethego - choć podkreślał idealizm ostatniego, protestując przeciwko nadużywaniu tej analogii - a korzenie nietzscheanizmu widział w niebezpiecznym, "plennie rozmnożonym plemieniu Fausta z części II”. Pisał też o „tragedii samotnych bohaterów” Ibsena, „pogardliwie spoglądających na biedną ludzkość” i walczących z filisterstwem, zaznaczając, że w Komedii miłości może również „mają rację «filistry»" (zob. H. Secomska, Władysław Bogusławski krytyk zapomniany, w: W. Bogusławski, Siły i środki naszej sceny, wstęp i oprac. H. Secomska, Warszawa 1961, s. 36-38; Myśl teatralna doby postyczniowej. Antologia, wybór i oprac. S. Brzozowska, M. Dybizbański, Opole 2016, s. 337-340, 357, 363).

17 W listach do córki Zofii z 10 stycznia i do Orzeszkowej z 11 lutego 1900 roku: „szelmy modernisty”, „bożki obojętności narodowej, społecznej i ideałowej [sic!]”, „szopka dekadentów, a raczej modernistów" (Listy do synów..., s. 454; Korespondencja, t. 2, oprac. E. Jankowski, Wrocław 1972, s. 75). 
artystycznym. Praktycyzm poczynionych uwag, pragmatyczny wymiar życiowych relacji i stereotypów - to trochę za niski pułap dyskursu dla autorki Imaginy; podobne dywagacje „w skali mikro” niezbyt pasują do jej wizjonerskich i post(neo)romantycznych wyobrażeń o artyście ${ }^{18}$.

Tylko częściowo koresponduje ze znanym stanowiskiem Konopnickiej zaprezentowana genealogia współczesnego „nadczłowieczeństwa”, od Goethego przez Carlyle’a po Nietzschego - ujęcie zgrabne, ale dość powierzchowne. Poetka niewątpliwie podzielała powszechne opinie swego pokolenia o twórcy Übermenscha ${ }^{19}$, także głośna wówczas Carlyle’owska koncepcja „kultu herosów" musiała być jej znana ${ }^{20}$ - ale już nietzscheańskiej kreacji Fausta zdaje się przeczyć entuzjastyczna opinia o dziele Goethego, dająca o sobie znać choćby w recenzji, jaką poświęciła przekładowi niemieckiego dzieła pióra Ludwika Jenikego ${ }^{21}$. Ponadto druga część Fausta, która według tendencyjnej oceny autora Artystów i filistrów „jest jednym hymnem zwycięstwa «silnych

18 Jako przykład można podać rozważania nad kondycją artysty ze wspomnianego szkicu Na ostrzu pióra; Konopnicka pisze tam z uznaniem o „wybujałym indywidualizmie, który wszelkie względy potocznego życia pomija, odrzuca, wyklucza”, i o „arystokratyzmie ducha, przeciwstawieniu siebie temu, co się nazywa tłumem”, które grożą wprawdzie wypaczeniem, ale dokumentują „siłę, jaką daje wyzucie się z zależności od ludzkiego sądu” (Publicystyka literacka i społeczna..., s. 431-432).

19 Listy z 1891 (do rodziny) i 1899 (do Orzeszkowej) zawierają określenia typu: „kupa paradoksów”, „ciekawy niesłychanie umysł”, „nie znam ducha większej pychy”, „krytyki [...] tak rozkładającej wszelką budowę myśli ludzkiej - świat nie widział jeszcze" (Korespondencja, t. 2..., s. 66; Listy do Ignacego Wasiłowskiego, oprac. J. Nowak, Warszawa 2005, s. 333, 339).

20 Nazwisko szkockiego historiozofa nie pojawia się w wyborze publicystyki Konopnickiej w opracowaniu Jana Baculewskiego. Do znajomości prac Thomasa Carlyle’a (1795-1885) bardzo przyczyniła się Historia literatury angielskiej Hippolyte’a Taine'a, a w Polsce tłumaczono go od początku lat osiemdziesiątych (Sygurd Wiśniowski). „Biblioteka Warszawska” (1892, t. 1) zamieściła omówienie anonimowego przekładu pism Carlyle’a (Bohaterowie. Cześć dla bohaterów i pierwiastek bohaterstwa $w$ historii, 1892) pióra Szymona Askenazego, który surowo ocenił zarówno osobę angielskiego pisarza, jak i jego koncepcje (polski historyk „wolałby może [...] żadnego utworu Carlyle’a nie widzieć w przekładzie polskim”; s. 586). Czy autor Artystów i filistrów inspirował się tekstem Askenazego? Została tam przywołana np. „cześć bałwochwalcza” Carlyle’a dla „największego geniuszu” Goethego (s. 582).

21 O kreacji legendarnej postaci literackiej Konopnicka powiada tam w sposób, który trudno kojarzyć z piętnem nietzscheańskim, bliżej mu raczej do interpretacji byroniczno-mickiewiczowskiej: „pierwiastek wiekuistej rozpaczy ducha ludzkiego”, „wrażenie pędu, który porywa jak wicher, tego upojenia, które ogarnia jak płomień, tej potęgi samorodnej, która jak grom otwiera duszę, aż do najskrytszych jej głębin” („Gazeta Polska” 1888, nr 285, s. 3). 
i wielkich»", nie przykuła specjalnej sympatii (uwagi) poetki ${ }^{22}$. Zastanawia też dygresja poświęcona Ibsenowi, świadcząca o wyraźnej fascynacji - nawet jeśli w sensie negatywnym - Peer Gyntem. W publicystyce Konopnickiej sporo odwołań do dramatu Ibsenowskiego znajdujemy w recenzji Święta pokoju Gerharta Hauptmanna („Biblioteka Warszawska” 1892, t. 1, z. 2). Przywołany tam zostaje szereg utworów norweskiego dramaturga (Hedda Gabler, Poślubiona morzu, Widma, Nora), ale Peer Gynta brak. Tymczasem należałoby zakładać, że osoba, która uważa tego bohatera za urągającego wartościom rodzinnym wyraziciela „katechizmu nadludzi” (tak w Artystach i filistrach), powinna co najmniej napomknąć o tym konflikcie w kontekście tragedii rodzinnej u Hauptmanna ${ }^{23}$. Ponadto wątpliwe jest, czy Konopnicka byłaby skłonna dokonać tak zniekształcającej i tendencyjnie uproszczonej interpretacji. Peer Gynta (jeśli go w ogóle znała ${ }^{24}$ ). Ten norweski anty-Faust to nie tyle apoteoza marzeń i czynu jednostki, co dobitne ukazanie jej klęski spowodowanej właśnie zaniechaniem obowiązków zwykłego życia.

Dziedzina plastyki była z pewnością bliska przyjaciółce Marii Dulębianki, autorce szkicu o pracowniach malarskich i wielu poetyckich ekfraz - tylko czy wywód tak wyraźnie zaangażowany w dzieje malarstwa francuskiego, a w imieniu polskich artystów ubolewający nad brakiem „atmosfery odpowiedniej dla rozwoju ich sztuki” w kraju, nie wydaje się raczej wskazywać na autora o bliższych relacjach ze środowiskiem artystów malarzy 25 ? Poważne zastrzeżenia budzi wreszcie styl wypowiedzi. Zgrabny i umiejętny, bez wątpienia wskazuje na rękę wprawnego literata, ale brakuje mu swady i polotu, jakie charakteryzowały wysmakowaną językowo publicystykę Konopnickiej ${ }^{26}$. Także „erudycja” tekstu - nie tyle głęboka, ile rzeczowa, nieco pe-

22 „Prawdziwa wdzięczność należy się zasłużonemu tłumaczowi za to, że nie obciążył książki swojej drugą częścią Fausta, której zresztą mamy już dwa, rzadko przez kogo czytane, a jeszcze rzadziej rozumiane przekłady" (tamże). Nie jest jasne, czy rezerwa ta dotyczy tłumaczeń, czy oryginału.

23 Dyskurs recenzentki Konopnickiej idzie całkiem innym torem: konsekwencji, jakie niesie dla poetyki dramatu obraz egzystencjalnego tragizmu codzienności. „Szkoła” i „doktryna Ibsenowska” wiążą się dla poetki głównie z „nierozwikłaną, szarą ową przędzą powszedniej tragiczności życia” (zob. Publicystyka literacka i społeczna..., s. 336,349 i in.).

24 Pierwszy przekład niemiecki - 1881, polski - 1910 (por. niżej).

25 Autorka Na ostrzu pióra daje wyraz większemu optymizmowi: „U nas umieją się ludzie wzruszać sztuką. [...] Jest to może trochę pierwotne jeszcze, ale bardzo żywe, bardzo o przyszłości mówiące” (tamże, s. 440).

26 Również Profesor Jolanta Sztachelska uważa, że styl artykułu jest zbyt mało poetycki, jak na Konopnicką. Doktor Lena Magnone jest zdania, że zarówno temat, jak styl i język szkicu nie dają podstaw, by mówić o autorstwie poetki. 
dantyczna, może nawet pretensjonalna, niezbyt licuje z poetyką tekstów Konopnickiej; podobnie obecność niektórych wyrazów ${ }^{27}$.

\section{JEŚLI NIE KONOPNICKA - TO KTO?}

W rozważanym okresie kryptonimem M.K. posługiwało się kilkanaście osób. Tylko z obowiązku należy wspomnieć o Marii Komornickiej (w 1897 ma dwadzieścia jeden lat i dwa lata wcześniej opublikowała współautorskie Forpoczty) - przesłanie tekstu Artyści i filistry jest zbyt moralizatorskie i obce pokoleniu debiutujących młodopolan, jak zresztą cały profil umiarkowanego pisma, by rozważać to autorstwo. Spośród potencjalnych kandydatów warto wziąć pod uwagę dwa nazwiska. Micha£ KonOPIŃsKi (1855-1928) był absolwentem historii i literatury na UJ, nauczycielem i działaczem oświatowym, a przede wszystkim publicystą demokratycznej „Nowej Reformy”, która pod jego świetną redakcją przeżyła rozkwit w latach 1894-1918. Krakowianin nie posiadał może „wybitnego talentu dziennikarsko-publicystycznego" ${ }^{28}$, ale niewątpliwie dysponował możliwością lektur niemieckojęzycznych, jak również dobrą orientacją w życiu artystycznym. Jako redaktor wykazał się ambicjami literackimi, nawiązując współpracę z plejadą ówczesnych pisarzy (m.in. Orzeszkową, Konopnicką, Dygasińskim, Tetmajerem, Żeromskim). Drugim podejrzanym byłby Maksymilian Kantecki (18571899), również historyk, pedagog i redaktor, od 1887 roku związany $\mathrm{z}$ „Kurierem Poznańskim”. Ma on na swoim koncie głównie prace historyczne, ale jako absolwent Uniwersytetu Wrocławskiego i członek Towarzystwa Literacko-Słowiańskiego mógł jeszcze swobodniej poruszać się wśród niemieckich publikacji filologicznych. Za autorstwem Kanteckiego przemawiałaby jego ugodowa (i zapewne tradycjonalistyczna) postawa, choć kontrargumentem byłaby biografia ograniczona do zaboru pruskiego. W sumie jednak, wadą obu kandydatur są zbyt nikłe tropy zainteresowań literackich. Informacje o pozostałych autorach, ukrywających się pod inicjałami M.K., nie otwierają obiecujących perspektyw ${ }^{29}$. Ciekawa natomiast jest poszlaka pro-

27 Np. sześciokrotne określenie „masy”, użyte w kontekście uwag o kulturze, sugeruje autora generacyjnie bliższego nowoczesności (u Konopnickiej termin ten, obok „hordy”, pojawia się w szkicu o socjologicznym i psychologicznym fenomenie „tłumu” oraz, epizodycznie, w rozważaniach o „naszym ludzie”; 1896, 1907). Poza tym Profesor Tadeusz Budrewicz zwrócił uwagę na fakt, iż nie leżało w zwyczaju poetki cytowanie oryginalnych tekstów niemieckich.

28 Był m.in. autorem felietonów wstępnych w „Nowej Reformie” (m.in. polityczno-satyryczny cykl Z uwag pesymisty, 1898-1907). Zob. PSB, t. 13, s. 562.

29 Maria KARCZEwsKa (1866-1951) - pochodząca z Białorusi, starannie wykształcona (znajomość sześciu języków, w tym niemieckiego) żona mławskiego ziemianina, 
wadząca do Mari Feldmanowej (1874-1953) - tłumaczki literatur germańskich, głównie niemieckiej i angielskiej, oraz autorki pierwszego polskiego przekładu Peer Gynta (Kraków 1910). Publikowała ona jako Maria KLeINMAN (nazwisko panieńskie do 1898) i Maria KreCzowsKa. Informacje na jej temat są jednak nader skąpe ${ }^{30}$.

Nie można też wykluczyć hipotezy, że autor wywodził się z grona mniej lub bardziej stałych współpracowników warszawskiego tygodnika. Podążając tropem zagadkowych inicjałów, można w nich odczytać drugie imię i nazwisko WaC£awa Mariana KarCzewskiego (1855-1911). Jako Marian Jasieńczyk ${ }^{31}$ opublikował wprawdzie tylko jeden tekst na łamach pisma (Istota i zadania powieści. Odpowiedź na kwestionariusz, KN 1897, numer $9 \mathrm{z}$ 17/28 lutego - numer bezpośrednio poprzedzający publikację Artystów i filistrów), ale nie można wykluczyć, że epizod współpracy objął dwie publikacje ${ }^{32}$. Koniec wieku to w biografii pisarza moment względnej swobody po uciążliwych latach warszawskiego dziennikarstwa: od 1894 do 1900 roku przebywa jako

od 1896 roku autorka wielu cennych prac i artykułów na tematy gospodarcze, społeczne i kulturalno-oświatowe, zasłużona działaczka i organizatorka; MicHA£ PAwLIK (1853-1915) - ukraińsko-polski działacz socjalistyczny, pisarz i publicysta, niedoszły absolwent lwowskiej humanistyki, „związany silnie z kulturą polską” tłumacz Reymonta i badacz spuścizny Kraszewskiego (zob. PSB, t. 12, s. 28; PSB t. 25/1, s. 427 n.).

30 W Nowym Korbucie nie ma wprawdzie inicjałów M.K. wśród pseudo- i kryptonimów Marii Feldmanowej, ale brak tam też takich danych, jak pierwodruk przekładu Peer Gynta, publikacje dziewiętnastowieczne czy jeszcze inny pseudonim tej mało znanej literatki, która według jednego z katalogów antykwarycznych była również poetką (zob. Nowy Korbut, t. 13, s. 499, t. 16, s. 398; H. Ibsen, Peer Gynt..., s. LXXV; „Lamus. Antykwariaty warszawskie. XLII Aukcja książki i grafiki, Warszawa 21.05.2016"). Z bibliografii Estreichera oraz (problematycznych) zapisów w katalogach BN wynika, że publikowała już w latach 90.: „ca. 1890?” jako Maria Kreczowska „ułożyła” (tłumaczyła?) Robinsona Cruzoe dla młodzieży „podług” Defoe, „ca. 1895” jako Eliza Warzycka „zebrała” wybór opowiadań (m.in. Wilhelma Hauffa) pt. Złota księga młodzieży, w 1899 roku jako Maria Kreczowska wydała przekłady Baśni i powiastek dla dzieci Jacoba Grimma (druk wszystkich pozycji: Wiedeń), ponadto w latach 1891-1900 publikowała w „Izraelicie” jako Maria Kleinman. W tej sytuacji kontrargumentem byłby nie tyle młody w 1897 wiek autorki (bo mogła zainteresować się Ibsenem dopiero pod wpływem męża; por. W. Feldman, Henryk Ibsen, 1906), ile zwrot „nasi młodzi”, użyty przez dwudziestotrzyletnią osobę.

31 Inne pseudonimy i kryptonimy pisarza to: M.J., Emjot, W.K., W...ski, Micz, Wasz, Fortunio, Helvetius, Jeden z wielu, Orientalista z okazji, Pra-pra-wnuk.

32 Niestety wśród archiwalnych materiałów, obejmujących zgromadzone przez autora wycinki prasowe, nie ma żadnej publikacji z KN (za pomoc w uzyskaniu informacji dziękuję pracownikom Pracowni Reprograficznej Biblioteki Zakładu im. Ossolineum). 
korespondent zagraniczny w Genewie, skąd nadsyła artykuły do wielu polskich czasopism i gdzie znajduje czas na ukończenie W Wielgiem (druk powieści od początku 1897). Być może w tym sąsiedztwie obu publikacji tkwił banalny powód ukrycia tożsamości; autor (redaktor) chciał uniknąć powtórki nazwiska w kolejnych numerach. W grę jednak mogły wchodzić także względy merytoryczne: szwagier Jacka Malczewskiego, pozostający w relacjach zarówno ze środowiskiem literackim, jak i malarskim, mógł bardziej niż inni obawiać się reakcji ze strony przywoływanych do porządku artystów. Ponadto, jako autor wymienionego szkicu o powieści, w którym zdecydowanie opowiedział się za estetyczną funkcją sztuki (właśnie sztuki w ogóle, nie tylko powieści), a przeciwko jej funkcjom utylitarnym - miał prawo spodziewać się zarzutów o niekonsekwencję, jeśli po wystąpieniu w obronie autonomii artystycznej poddał krytyce elitaryzm jej przedstawicieli. Co istotne, fakt epizodycznej współpracy Jasieńczyka z „Kurierem Niedzielnym” wcale nie świadczy o jego luźnych związkach z tym środowiskiem, wprost przeciwnie; odpowiedzi na rozpisaną przez redaktora ankietę o powieści udzieliły niemal wyłącznie osoby wywodzące się z grona jego bliskich współpracowników, z których większość, podobnie jak Karczewski i sam Grendyszyński, reprezentowała drugie pokolenie pozytywistów ${ }^{33}$. Jest to o tyle istotne, że tekst $A r-$ tyści i filistry ukazał się jako ostatni z trzech kolejnych „wstępniaków”, napisanych w zastępstwie nieobecnego chwilowo redaktora. Dwa wcześniejsze (nry 8 i 9) przygotowali Stanisław Hłasko oraz Wincenty Kosiakiewicz (Gros), należący do najbardziej aktywnych publicystów „Kuriera” - a z tym ostatnim Karczewski napisał w 1890 roku Komedię do spółki. Mało prawdopodobne, by redakcja poprosiła o takie zastępstwo na przykład Marię Konopnicką, mogła natomiast z powodzeniem zwrócić się z tą propozycją do Jasieńczyka (jego nazwisko zapowiadał numer inicjalny). Jego autorstwo mogą także potwierdzać przesłanki tekstologiczne. Karczewski dramaturg, autor głośnej w swoim czasie Leny (1885), był naturalną koleją rzeczy żywo zainteresowany twórczością Ibsena (pobyt w Szwajcarii mógł stanowić okazję do pogłębienia tej wiedzy). Miał na swoim koncie tłumaczenia z Heinego. Jako i literat, i osoba bardzo blisko związana $\mathrm{z}$ kręgami malarzy, był zorientowany w kierunkach w sztuce (impresjonizm, modernizm) oraz poruszony skandalami z udziałem Antoniego Kurzawy i Władysława Podkowińskiego. Jego oparta na emocjonalizmie teoria autonomii sztuki wcale nie wykluczała postulatu

33 Zob. A. Mazur, Przyczynek do kwestii estetycznej około roku 1897, w: Poetyka losu i historii. Profesorowi Tadeuszowi Budrewiczowi w sześćdziesiątą piątą rocznicę urodzin, red. K. Gajda, R. Stachura-Lupa, K. Wądolny-Tatar, Kraków 2017, s. 517-538. 
uniwersalnej ludzkiej wspólnoty ${ }^{34}$; co więcej, tłumaczyłaby ubolewanie nad polskim zapóźnieniem estetycznym („na każdym kroku [...] znać niedawne na tym polu barbarzyństwo”). Znamienny zwrot „nasi młodzi” byłby też zrozumiały u ucznia Adolfa Dygasińskiego, bliższego zastanej tradycji niż „nietzscheańskim” orientacjom modernistycznym. Nie można zresztą wykluczyć ironii tego określenia, użytego jako cudze słowo; dystans mentalny generacji Karczewskiego do młodopolan był jednak mniejszy niż generacji wcześniejszych. Przejściowość drugiego pokolenia umożliwiała takie ambiwalentne stanowisko, między-generacyjnie czy między-epokowo pojednawcze: $\mathrm{z}$ jednej strony krytyczny dystans wobec przesadnych roszczeń artystowskich z perspektywy etosu życia zwyczajnych ludzi, z drugiej - uznanie dla nowości artystycznych oraz ton lekkiej wyższości wobec zdezorientowanej „publiczności”. Jeśli chodzi o stronę formalną wypowiedzi - obok wprawnej, acz nie mistrzowskiej strony językowej - zdradza ona pewien charakterystyczny szczegół, właściwy tekstowi Jasieńczyka: częste (nad)używanie cudzysłowu w celach ekspresyjno-stylistycznych. W szkicu o powieści zabieg ten pojawia się około dziesięciokrotnie, w Artystach i filistrach ośmiokrotnie. Poza tym oba teksty przy zdyscyplinowanym, rzeczowym dyskursie zdradzają równocześnie emocjonalność wypowiedzi (wykrzyknienia, pytajniki) ${ }^{35}$.

Oprócz Karczewskiego zaproponować można jeszcze dwa hipotetyczne nazwiska z grona stałych publicystów czasopisma, choć powiązanie ich z kryptonimem M.K. opiera się na przesłankach logicznie dość wątłych. Pierwszy kandydat to Marian GaWALEWICz (1852-1910), jeden z najaktywniejszych współpracowników; jego teksty - z reguły w ramach rubryki Przegląd dramatyczny lub Przegląd teatralny - ukazały się w blisko czterdziestu numerach, przy czym dziesięć z nich to szkice lub felietony wstępne na stronie tytułowej. Ponieważ Gawalewicz używał kilkunastu różnych pseudo- i kryptonimów ${ }^{36}$, dołożenie do tej listy jeszcze jednego jest ryzykowne, lecz dopuszczalne, tym bardziej że posługiwał się kombinacją głoski „K”. Najciekawszą

34 Dla Karczewskiego estetyczna funkcja sztuki sprowadzała się do „wywoływania” egalitarnych „Wrażeń”: „WZRUSZANIE w najobszerniejszym znaczeniu określenia tego, oto jedyny [...] cel i racja bytu [sztuki] [...]. Stopień wrażliwości społecznej to jeden z nieomylnych wskaźników stopnia społecznej kultury” (KN 1897, nr 9, s. 98-99).

35 Teza o autorstwie Karczewskiego wymagałaby dokładniejszego przebadania jego publicystyki, choć niewiele zawiera ona tekstów porównywalnych z tymi dwoma; dominują recenzje-omówienia, utrzymane na niższym poziomie erudycyjnym, reprezentujące potoczny styl wypowiedzi.

36 Długi, G., GCz, Gez., Konstanty Borejko, Konstanty, M. Borejko, M.G., M. Gaw., Mar. Ga., Maryan, MN, N, Ostrowidz, Przygodny, Quis, Q - i ich warianty (w KN obok pełnego imienia i nazwiska pojawiają się: M.G., Quis i Q). 
poszlaką w jego przypadku byłby utwór Filistry. Powieść społeczno-obyczajowa (1888). Pisarz zawarł tam modelowy obraz autentycznego filisterstwa warszawskiej burżuazji (podobno uchwyconej z autopsji), w której środowisku marzenia niedoszłego idealisty ulegają moralnemu rozkładowi, a on sam staje się typowym wcieleniem filistra. Inne fakty, mogące przemawiać na korzyść tego autorstwa, to tłumaczenia z niemieckiego (w tym Heinego, druk. 189o), oczytanie pisarza w literaturze europejskiej ${ }^{37}$ - a zwłaszcza zafascynowanie teatrem oraz popularyzowanie nowatorskiej twórczości Ibsena - przy jednoczesnej krytycznej ocenie pesymistycznego „moralnego charłactwa" modernistów i naturalistów ${ }^{38}$. Jawnie tendencyjny, dydaktyczny charakter pisarstwa Gawalewicza, jego „dyletanckie, ale rozległe zainteresowania, łatwość pióra oraz umiejętność przystosowania się do panującej mody literackiej" ${ }^{39}$ dobrze korespondują z charakterem omawianego tekstu.

Ostatnią kandydatką byłaby MARIA CHeŁmońsKA (1861-1942) - wydawczyni i główna redaktorka tygodnika. Hipoteza wyjaśnienia zagadkowego podpisu opierałaby się tutaj na ewentualnych asocjacjach z rodowym nazwiskiem żony Józefa Chełmońskiego: Korwin-Szymanowska. Naczelna „Kuriera Niedzielnego" była autorką kilkunastu tekstów (sygnowanych pełnym imieniem i nazwiskiem bądź inicjałami M.Ch.), w tym dwu zamieszczonych na stronie tytułowej; przeważnie były poświęcone sztuce (muzyce), rzadziej sylwetkom polskich literatów. Byłoby rzeczą bardzo naturalną, gdyby to właśnie ona, w zastępstwie Grendyszyńskiego, napisała jeden z artykułów wstępnych. Rozbudowany wywód o perypetiach sztuki francuskich impresjonistów, o tradycjach niemieckich burszów po 1848 roku, wyakcentowanie trudności rozwoju talentów na gruncie rodzimym, podkreślenie zjawiska emigracji polskich artystów malarzy oraz bolesnej dysharmonii między twórcami a odbiorcami sztuki w kraju, znajomość bardziej szczegółowych faktów związanych z dolą i niedolą malarzy (wzmianka o powieści Émile’a Zoli Dzieło, poświęconej Édouardowi Manetowi i dramatowi artysty) - to wszystko korespondowałoby z wiedzą oraz doświadczeniami byłej (po 1894) żony malarza-emigranta w Paryżu w latach 1878-1887. Mniej wytłumaczalny byłby zapewne wątek ibsenowski. Jeśli chodzi o poziom emocjonalnego, dydak-

37 Podobnie jak autor Artystów i filistrów, Gawalewicz w jednej ze swoich recenzji przytacza fragment utworu (Don Juan i Faust Christiana Dietricha Grabbego) w języku niemieckim (zob. Przegląd teatralny, „Ateneum” 1890, t. 1, s. 133).

38 Zob. I. Maciejewska, Marian Gawalewicz, w: Literatura polska w okresie realizmu i naturalizmu, red. J. Kulczycka-Saloni, H. Markiewicz, Z. Żabicki, t. 2, Warszawa 1966, s. 343. Określenie pochodzi z powieści Gawalewicza Mgła (1893).

Tamże, s. 338 . 
tycznego zaangażowania wypowiedzi, postulat docenienia pracy zwyczajnych, solidnych członków społeczeństwa, ocenionej jako wartościowsza niż wzloty pseudoelit artystycznych (czyżby też obserwacje i wnioski z autopsji?) tendencje te można spotkać także w innych tekstach Chełmońskiej, na przykład w pochwalnym portrecie społecznie zaangażowanej, wzorcowej obywatelki i kobiety, Marii Ilnickiej.

Choć podobne tropy można by mnożyć ${ }^{40}$, wskazane powyżej budują krąg chyba najbardziej prawdopodobnych, hipotetycznych autorów. Niezależnie jednak od tego, kto tym autorem był w istocie, tekst Artystów i filistrów sam w sobie stanowi cenne świadectwo gorących sporów, typowych dla modernistycznego okresu burzy i naporu - a także próbę zajęcia wobec nich wyważonego, zdroworozsądkowego stanowiska. Próbę bezskuteczną, jak wykazały dzieje krytyki literackiej. W pamięci potomnych miały pozostać donośniejsze głosy „naszych młodych” gniewnych.

W tekście została zmodernizowana fleksja, ortografia (w tym pisownia nazwiska Nietzschego i słowa Sonntagsröcklein) oraz interpunkcja. Zachowano oryginalny układ graficzny publikacji.

40 Jak np. - dziękuję za trop podsunięty przez Panią Redaktor Magdalenę Rudkowską - postać MaKsymiliana KAWCZý́sKiego (1842-1906), pochodzącego z Wielkopolski, a zamieszkałego później w Krakowie, profesora UJ, germanisty, romanisty, językoznawcy i publicysty. 
M.K.

\section{ARTYŚCI I FILISTRY*}

\section{(opracowała i artykułem wstępnym opatrzyła Aneta Mazur)}

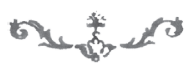

W różnych czasach i epokach istniał zawsze pewien przedział i antagonizm, pewne wzajemne niezrozumienie się między artystą, poetą a spokojnym obywatelem i w ogóle między wszystkim, co młode, co nowe, co się pcha naprzód, co walczy, co zdobywa, a tym, co uznane i przeciętne, co nie jest marką nową, ale monetą dawną, kurs w kraju mającą. Dzisiaj jednak przedział ten znacznie pogłębiony został, a niezrozumienie się przybrało rozmiary wzajemnego lekceważenia.

Przyczyniły się do tego nowe kierunki tworzenia w sztuce, nowe rodzaje formy, wśród których szersza publiczność nie umie się orientować; modernizm w literaturze, impresjonizm w malarstwie nie przeniknęły do mas i pozostawiają je w najlepszym razie w chłodnym usposobieniu, jeżeli już nie w zgoła wrogim lub szyderskim.

Artyści, niezachęceni przez publiczność, a przede wszystkim zrażeni brakiem odczucia, cofnęli się do swego Empireum, zamknęli w sobie i pogardzając niedojrzałymi sądami ogółu, chcą teraz tworzyć wyłącznie dla siebie, dla wyrażenia prawdy estetycznej tak szczerze, jak ją pojmują.

Dysonans ten i rozdwojenie jest u nas głębsze niż w krajach o kulturze wyższej i większym wyrobieniu estetycznym. U nas wszystkie warunki przeszkadzają rozwojowi sztuki i przenikaniu jej do mas - stąd też masy te odczuwają ją tylko wtedy, gdy je tematem zajmie i poruszy, potrącając o jakieś uczucie, w głębi serca drzemiące.

* Pierwodruk: „Kurier Niedzielny” 1897, nr 10 (23 lutego/ 7 marca), s. 109-111. Przypisy - jeśli nie zaznaczono inaczej - pochodzą od autorki opracowania. 
We Francji to niezrozumienie NOWYCH kierunków artystycznych, stało się już legendą, umarło w rzeczywistości i mogło powstać w pieśni, więc odtworzył ją po mistrzowsku Zola, dając w swoim CEuvre z przerażającą prawdą historię życia, walki i zapoznania Maneta, twórcy impresjonizmu. Dziś czasy się zmieniły: obrazy Maneta sprzedawane są na wagę złota, a nowe prądy przeniknęły nie tylko do pracowni artystów, ale i do pojęć całego społeczeństwa francuskiego. Dziś już nie usłyszymy na wystawach obu „Salonów" tego bezmyślnego i okrutnego śmiechu, który do rozpaczy doprowadził Klaudiusza Lantier.

U nas śmiech taki jest pospolitym zjawiskiem przy każdym pojawieniu się dzieł młodych artystów, mających ideały artystyczne, różne od ideałów publiczności. Niedaleka to przeszłość, gdy dwóch przedstawicieli nowych kierunków (Kurzawa i Podkowiński) ${ }^{1}$ targnęło się w nerwowym podnieceniu na własne dzieła, aby je zniszczyć i uchronić od dorywczych sądów niepowołanych krytyków.

Trzeba przyznać, że to jest zaklęte koło bez wyjścia. Nowe kierunki, aby zwyciężyć, potrzebują więcej może niż dawniejsze genialnych przedstawicieli - a o sprzyjające warunki dla wyrabiania się talentów tak trudno, tak niewypowiedzianie trudno na naszym gruncie! Publiczność znów nie ma sposobności ani możności materialnej wyrobienia gustu i poczuć estetycznych... i wiele okoliczności musiałoby się zmienić, aby mogła nastąpić harmonia i zrozumienie się między artystami i społeczeństwem.

Wśród młodzieży artystyczno-literackiej, a nawet wśród młodzieży należącej do jakiegokolwiek ruchu umysłowego, upowszechniło się pewne wyosabnianie się, wytwarzanie rodzaju koła zamkniętego, żyjącego dla siebie i w sobie sztuką, ideą - w przeciwieństwie do reszty ludzi zwyczajnych, objętych ogólną nazwą filistrów.

Nazwa nie nowa, a nawet bardzo stara: urodziła się w Niemczech, zyskała prawo obywatelstwa wśród burszów uniwersyteckich, a rozpowszechniła się szczególniej około 1848-go roku.

W owym to czasie wielkiego wrzenia umysłów, w krótkiej poetycznej do-

1 W 1890 roku utalentowany rzeźbiarz Antoni Kurzawa (1842-1898) rozbił swoją wystawioną na konkurs rzeźbę Mickiewicz budzący geniusza poezji (1889), nie otrzymawszy za nią żadnej nagrody; wydarzenie to złamało go psychicznie (zmarł w przytułku). W 1894 roku malarz Władysław Podkowiński (1866-1895) z niejasnych do końca pobudek i w geście protestu pociął swój kontrowersyjny obraz Szał uniesień (1893-1894). 
bie studenckiego życia, ten bursz niemiecki kipiał jak piana na brzegu kufla z piwem, szumiał i palił się do wszystkich idei postępowych. Chciał poprawić świat, zmienić społeczeństwo, a nawet wywrócić je do góry nogami - toteż pogardzał mieszczaninem zachowawczym, drżącym o całość swego zdrowia i kieszeni. Nazwał go filistrem, co było synonimem małoduszności, zaśniedziałego konserwatyzmu, egoistycznych zamiłowań i ociężałości umysłowej.

Taki to typ smagał ironią Heine: Philister in Sonntagsröcklein... ${ }^{2}$.

Dziś pojęcie filistra rozszerzyło się jakoś i zmieniło; szafujemy tą nazwą stanowczo zanadto, ogarniając nią nie tylko tych, co zasklepieni wśród małostkowych interesów prywatnych nie umieją się podnieść do poczucia i ogarnięcia interesów społecznych, ale i tych, co mając te wszystkie poczucia i pracując w swoim zakresie, unikają ekscentryczności, spoglądają z pewną nieufnością na „nowe kierunki” i nie dość dobrze „młodych” rozumieją.

Ten rodzaj zapatrywania się nie tylko u artystów młodszej generacji - ale u wszystkich ludzi wybitnych i prowadzących ludzkość na tory nowe jest naturalnym - ale mało sprawiedliwym. On to sprowadza coraz większy rozdział społeczeństwa na duchy wybrane, wyższe, krążące w sferze własnych ideałów i na wielkie mrowisko ludzi zwyczajnych, szarą masę będącą tylko tłem, podkładem dla tych „Übermenschów”; rozdział w skutkach swoich smutny, bo niszczący w zarodach wielki wpływ, jaki ci ludzie wyżsi mogliby wywierać na społeczeństwo, odbierający „nawet artystom i bohaterom” rację bytu. Bo racją bytu ich jest - ogrzewać, zapalać i prowadzić masy drogą postępu do coraz wyższych przeznaczeń i skracać rzutem genialnej myśli mozolną drogę, którą ludzkość dąży ku udoskonaleniu. A jakże ten może prowadzić, kto zapomniał języka, jakim wódz przemówić winien do tych, co mają pójść za nim?

Nie tylko zniechęcenie, wywoływane niezrozumieniem, odstręcza dziś artystów i ludzi żyjących ideą od zwykłych śmiertelników. Niezrozumienie to

Wiersz z cyklu Intermezzo liryczne (Księga pieśni, 1824). Szerszy kontekst cytatu (przeł. S. Łempicki): „Filistry w surdutach od święta / Przez łąki się włóczą i las / I skaczą jak młode koźlęta, / I mówią, że piękny jest czas. // Ich oczy aż błyszczą, wlepione / W «romantyzm» tych kwiatów i drzew./ A długie ich uszy, wzniesione, / Wchłaniają wróblęcy śpiew" (H. Heine, Dzieła wybrane. Utwory poetyckie, oprac. A. Sowiński, wstęp R. Karst, przekł. zbior., Warszawa 1956, s. 120). Księga pieśni była przełożona na polski już w 1876 roku; fakt przytoczenia oryginału mógłby przemawiać za galicyjskim rodowodem autora. 
istniało zawsze do pewnego stopnia, z wyjątkiem szczęśliwych epok i krajów, gdy artyści i lud przenikali się wzajemnie i wytwarzali razem atmosferę podniośle artystyczną, np. w Grecji, w Atenach za Peryklesa, we Włoszech w czasie Odrodzenia. Jest inna przyczyna, zamieniająca słuszne poczucie swej wartości u ludzi wyższych w dumę, która łatwo może się wyrodzić w pychę - a idąc dalej - w przewrotność.

Kilku myślicieli genialnych rzuciło paradoksalną teorię dzielenia ludzkości na duchy wyższe i niższe - na królów i pionków.

To, co było dotąd uważane za grzeszną zarozumiałość, zostało podparte i usankcjonowane zasadą filozoficzną. Pierwszy dał hasło tego śmiałego rozdziału Goethe, którego druga część Fausta jest jednym hymnem zwycięstwa „silnych i wielkich”.

Potem Carlyle (Bohaterowie ludzkości) dowodził słuszności przewagi i panowania geniuszów i uprawniał ich despotyczne roszczenia. W końcu przyszedł Nietzsche, wszystkie te pojęcia rozwinął, rozszerzył i zbudował z nich teorię „Übermenschów”. Dla tych „nad-ludzi” i tylko dla nich istnieje świat, piękno, sztuka i jej skarby, oni tylko rozumieją ducha czasu i są jego tłumaczami, oni tylko zdolni są pojąć prawdziwe piękno natury, oni mają poczucie na światła i cienie, na barwy i dźwięki - oni wreszcie mają prawo dbać wyłącznie o kształcenie i wyrabianie swego ducha według własnych pojęć o doskonałości; dla tego jedynego celu poświęcić wszelkie inne cele, względy i prawa i nie liczyć się z nikim i z niczym.

Co ich mogą obchodzić ciasne prawa moralności? Rodzina?... Ona tylko krępuje lot geniusza i wiąże mu skrzydła. Obowiązki społeczne?... To jeszcze powijak [sic!] dla myśli samodzielnej, która ponad wszelkie prace zbiorowe, mozolne, mrówcze woli się wzbijać pod niebo, bujać nad przepaściami, przebywać w orlej dziedzinie! Jest wiersz Ibsena (dzieło młodości, pierwszy szkic do Peer Gynta ${ }^{3}$ ) o tyle poetyczny, o ile przewrotny, który może być uważany za wyraz, za ostatnie słowo katechizmu nadludzi.

W poezji tej wiele, wszystko im przebaczono, nie dlatego, że jak Magdalena „wiele ukochali”, ale dlatego, że im wszystko wolno.

Bohater Ibsena porzuca starą matkę i chatę rodzinną w dolinie i pracę około roli - i dziewczynę, którą kochał i obiecał poślubić - bo go duch gór

3 Im Hochgebirge. Tłumaczenie niemieckie L. Pasarge [sic! - przypis M.K.]. Ludwig Passarge (1825-1912) był pierwszym niemieckim tłumaczem Ibsena, jego przekłady Peer Gynta ukazały się w 1881 i 1887 roku. Cytowany poniżej fragment pierwotnej wersji utworu Ibsena mógł polski publicysta przytoczyć albo za wstępem tłumacza do tych przekładów, albo za jego obszerną monografią Henrik Ibsen. Ein Beitrag zur neuesten Geschichte der norwegischen Nationalliteratur, Leipzig 1883. 
ciągnie wysoko ponad chmury. Idzie kąpać czoło w powietrzu górskim i spoglądać w niebiosa, mierząc się z orłami skalnymi - patrzy z niedostępnego urwiska, jak mu się chata pali, jak stara matka umiera, a kochanka tęskni i rozpacza - widzi potem, jak ta ostatnia, nie mogąc go się doczekać, idzie za mąż za innego - wtedy rzuca jej szydercze przekleństwo i zostaje na zawsze „w górnej krainie”, wśród gromu błyskawic i szumu potoków, zostaje sam ze sobą, bez wyrzutów sumienia, zapatrzony w ducha gór i poezji, rozgrzeszony, wielki, wzniesiony do apoteozy:

\author{
Ich schwang mich auf die Höhe des Lichts \\ Um die Dinge von oben zu schauen... \\ ...Nun bin ich gestählt, \\ Ich folg dem Gebot: \\ Ich soll auf der Höhe wandern! \\ Mein Leben im Thal für immer tot \\ Hier oben Gott und der Morgenrot, \\ Dort unten toppen die Andern! ${ }^{4}$
}

Co za pogarda w tym toppen, które ma oznaczać krzątaninę pospolitych ludzi i koło chleba powszedniego, i koło interesów rodzinnych, i około interesów swego zakątka - swego kraju!

Geniusz nie chce być kółkiem maszyny społecznej - on jest iskrą, która zapala. Prawda - ale ta iskra powinna wszystkie owe małe kółka w ruch wprowadzić, powinna być motorem społecznym. Jakże jednak zapali i w ruch wprowadzi, gdy buja samopas, jak ognik błędny rozkoszując się własnym światłem i ciepłem, zamiast lecieć prosto przodem przed tłumem i wieść ten tłum ku górze i błękitom niebieskim? A przecież być owym słupem ognistym, który wiódł Izraelitów wśród spiekłej puszczy do obiecanej krainy - to rola i przeznaczenie geniusza.

Jeżeli teoria o „nad-ludziach” zawrotną jest i obosieczną dla umysłów prawdziwie genialnych, to staje się mieczem w ręku szalonego dla setek głów niedowarzonych, talentów miernych i nieuzasadnionych ambicji. Wypacza charakter, rozdyma grzeszną pychę, wyradza dziwolągi artystyczne i literackie i przynosi w swym zastosowaniu nieobliczoną szkodę artystom i społeczeństwu.

4 Wzniosłem się do góry ku światłu, - Aby spojrzeć na świat z góry - Zahartowany jestem teraz, opancerzony - Słucham rozkazu, aby w górnej mieszkać krainie - Życie moje w dolinach skończone na zawsze - Tu w górze Bóg i świtanie jutrzenki, Tam w dole pełzają drudzy [przypis M.K.]. 
Kiedyś, w czasach romantyzmu, rozdźwięk między życiem mieszczańskim a pragnieniem artystycznej wolności wytworzył cyganerię literacką, przyjmującą formy oryginalne, nieraz śmieszne. Dziś formy te wydają się przestarzałe, treść jednak została ta sama, a nawet rozdźwięk ten jest znacznie większy, bo sięga głębiej.

Romantyczny cygan artystyczny gardził przyzwoitym ubraniem i przybierał strój zaniedbany a sobie właściwy, przesiadywał w kawiarni, omijając najstaranniej porządne towarzystwo, rozumiał jednak uczucie proste, mniej był skomplikowany od dzisiejszego artysty - a od filistrów wymyślał ludziom, nierozumiejącym wyższych celów i utopionym w egoizmie.

Dzisiejszy nadczłowiek nie różni się strojem od zwyczajnego śmiertelnika, ma nawet często zamiłowanie do wyszukanej wytworności, wysubtelnione jego poczucie estetyczne częściej prowadzi go do salonu niż do knajpy i każe mu szukać towarzystwa różnych ludzi - gardzi on jednak nimi w głębi duszy, a lekceważy nie tylko tych, którzy go odpychają małodusznością i poziomością celów, nawet nie tylko tych, co z szlachetnością uczuć łączą obojętność dla sztuki, a zatem jego nie są zdolni zrozumieć; on ma jeszcze pogardliwe lekceważenie dla tych wszystkich dusz prostych, poddających się pod prawo obowiązków, których jego własna dusza skomplikowana, złożona i wybujała nie uznaje i nie rozumie.

On z Ibsenem szydzi ze spokojnego, familijnego życia, zabijającego według niego natchnienie i twórczość, boi się małżeństwa jak ognia; miłość uznaje i wielbi, ale o tyle, o ile go ona nie przykuwa do ciężkiej taczki obowiązków - a poddanie się tym obowiązkom, włożenie szyi w jarzmo stawia pod pręgierz śmieszności w osobie Strohmana (Ibsen, Komedia miłości).

Zapatrzony w słońce sztuki, zapomina, że poza sztuką są uczucia wzniosłe w swej prostocie, są poświęcenia ogromne, a ciche i wielkie cele społeczne, do których prowadzi długa, wytrwała i pełna zaparcia się praca jednostek. W dumnym poczuciu swej wielkości, czując się wybraną istotą, zatraca w sobie poczucie spójni z tą rzeszą cierpliwą, niezrywającą się z wędzidła, odwyka od niej, nie ma z nią nic wspólnego.

W naszym kraju komplikuje się jeszcze ta kwestia przymusowym przebywaniem większości naszych artystów za granicą, bo wśród własnego społeczeństwa nie tylko atmosfery odpowiedniej dla rozwoju ich sztuki, ale po prostu chleba powszedniego dla nich zabrakło. Idą więc te duchy wyższe odosobnione od innych ludzi, tworząc klan zamknięty, odgrodzony od społeczeństwa swego smutkiem, goryczą i pychą.

Szlachetna duma i przekonanie o swej wyższej wartości nie szkodziłoby im, bo mają do niego prawo - gdyby się wspierało na miłości, na spójni 
duchowej z resztą swego narodu, na zrozumieniu swej uboższej duchem braci.

Pierwszym szczeblem zbliżenia się wybrańców sztuki ze zwyczajnymi ludźmi musi być sprostowanie mylnego pojęcia tych ostatnich ${ }^{5}$ o filisterstwie. Trzeba temu pojęciu przywrócić dawne znaczenie, które wskutek zbytniej wybujałości artystów i zmienienia się tych ostatnich w nadludzi utraciło; trzeba, żeby się artyści nauczyli odróżniać filistrów od tych ludzi zwyczajnych, którzy nimi nie są, żeby lekceważąc słusznie pierwszych, uszanowali w drugich prostotę pojęć i chęci, pracę płodną i wytrwałą i szlachetne zamiłowanie obowiązku.

Filisterstwo jest to zmaterializowanie, połączone z bezmyślnością. Filistrem jest człowiek, dla którego używanie jest celem życia, który poza sobą i swoją rodziną nic nie widzi, ani Boga, ani kraju, ani społeczeństwa, ani sztuki, to jest nie ma tych wszystkich pięknych haseł w sercu, choć je miewa zbyt często na ustach - któremu małe interesa jego kółka, koterii lub towarzystwa wystarczają.

Filistrem jest wielki pan, przegrywający w klubie setki tysięcy i żona jego, biegająca cały dzień po wizytach i magazynach - i nic mu to nie przeszkadza być filistrem, to jest człowiekiem o małych, egoistycznych celach, choć ma kilkanaście pierwszorzędnych obrazów na ścianach swych salonów i kolekcję japońskiej porcelany, choć zwiedził prawie wszystkie muzea europejskie, potrafi odróżniać dawne „szkoły”, a nawet ma pewne zamiłowanie w pejzażach impresjonistycznych.

Filistrem jest bankier, nadęty próżnością i najnędzniejszą pychą - pieniężną; filistrem obywatel wiejski, niewidzący nic poza swoimi zaściankowymi interesami, nieogarniający położenia kraju, którego jest członkiem, nieczujący tego wielkiego ruchu maszyny, której jest jednym kółkiem, myślący o dobrym obiedzie, o polowaniu i partyjce karcianej; - filistrem również urzędnik, i żona jego, szczyt filisterstwa, pani Malinowska (Alfred Konar, Siostry Malinowskie ${ }^{6}$, chowająca córki na towar mogący się dobrze sprzedać na targu małżeńskim.

Cały ten szereg postaci, tłoczących się na wielkim jarmarku próżności, pchających się naprzód, potrącających wzajemnie, czy one należą do wiel-

5 Zwrot niezbyt logiczny w kontekście; intencją autora jest pouczenie artystów, by adekwatnie posługiwali się określeniem „filister”, chodzi zatem raczej - czy głównie - o „tych pierwszych”.

6 Powieść Siostry Malinowskie Alfreda Konara (Kinderfreunda) ukazała się w 1894 roku w Warszawie. 
kiego, czy do małego świata, wszystkie te istoty bez ideału w życiu, bez celu wyższego, bez szczerej miłości bliźniego w sercu, bez poczucia obowiązków społecznych - to są filistry.

Trzeba przyznać, że społeczeństwo nasze do niedawnego czasu najmniej ze wszystkich europejskich zarażone było filisterstwem.

Od tej zarazy zmaterializowania i powolnego stężenia ducha w bezmyślnym używaniu, na które umierają społeczeństwa zachodnie, chroniła nas rycerskość, przechodząca prawem atawizmu na wnuki wojowniczych dziadów, i butna fantazja młodego jeszcze bądź co bądź narodu.

Odkąd po strasznych doświadczeniach, po upadku złudzeń wywiesiliśmy wielki sztandar pracy, filisterstwo przyczaiło się pod nim i z pięknego godła wykroiło sobie wygodną sukienkę.

Toteż widzimy dziś w wielu dziedzinach społecznego życia apatię, ogarniającą umysły, widzimy upadek ducha, zesłabnięcie energii, zasklepienie się w sobie i zamknięcie w kole ciasnej prywaty. Widzimy, jak na tych „dzikich polach", ogołoconych z wszelkich kwiatów zdrowej, zbiorowej działalności zaczyna się rozrastać filisterstwo w wielkie krzewy ostów i bodiaków.

Nad filisterstwo tego rodzaju nie ma nic niebezpieczniejszego. Jest to straszna choroba, filoksera, tocząca naszą winnicę, na którą wkrótce może zabraknąć ratunku, jeżeli się wcześnie nie zabierzemy do wytępienia jej ze szczętem. Jest to cisza morska, więcej przerażająca niż wichry i burze, śmierć głodowa, powolne zamieranie organizmu.

I nie wolno nam mówić, że stan ten jest nieuniknioną fatalnością - jest on tylko wynikiem naszej słabości, znamienną cechą naszego charakteru, któremu łatwiej było przez lat sto wytaczać krew swoją własnymi rękami, niż zdobyć się na codzienną, żmudną, drobiazgową wytrwałość.

Toteż pierwszym naszym obowiązkiem jest bronić się przeciw tej bezwładności, zwalczać ją wszelkimi siłami. Pamiętajmy, że wiele ten robi, kto ma wiele miłości w sercu i wyrzeknie się zupełnie próżności. Niech każdy pracuje w małym kółku, najprzód nad sobą, niech się stara podnieść duchowo, wyrobić siłę moralną w sobie i w swoich...

Potrzeba jednak na to, aby między artystami a resztą narodu nie było zbyt wielkiej przepaści. I zdaje mi się, że artyści, sądząc zwyczajnych ludzi, mieszają często prostą nieznajomość sztuki i brak wyrobienia estetycznego z tym grzesznym filisterstwem, o którym mówiliśmy przed chwilą.

Nazywają oni nieraz filisterstwem trwanie w pracy cierpliwej, w obowiązkach zwyczajnych i wykonywanie katechizmowe surowej powinności, 
które tym duchom wolnym, żadnych pęt nieuznającym, wydaje się poziomością.

Prawda, zdarza się czasem, że ludzie szlachetni, oddani płodnej pracy społecznej, wobec sztuki i jej kapłanów zachowują się jak filistry, choć nimi nie są właściwie.

Dzieje się to zwłaszcza u nas, gdzie pod względem estetycznego wychowania wszystko jeszcze jest do zrobienia, gdzie na każdym kroku brak kultury i znać niedawne na tym polu barbarzyństwo.

Przy wydawaniu sądu o tych ludziach nie powinni artyści zapominać, że bądź co bądź sztuka jest tylko jednym promieniem tego światła, którym życie narodowe strzela ku niebu, być może najcieplejszym i najjaśniejszym, ale... jednym wśród kilku innych, a nie jedynym.

Może ten promień prędzej przeniknie szarą masę pospolitych ludzi, gdy artysta i poeta $\mathrm{z}$ nad-człowieka stanie się na powrót po prostu człowiekiem w najpiękniejszym znaczeniu tego słowa. Gdy przyjąwszy na siebie ciężar zwyczajnych obowiązków, uszlachetnić je potrafi przez pojmowanie wyższe i wykonywanie niepospolite, a nie usuwając się od uczuć rodzinnych, znajdzie w nich spokój i harmonię.

Dla sztuki żyć! -

To znaczy żyć dla świata

- powiedział jeden $\mathrm{z}$ „naszych młodych” (Lucjan Rydel) ${ }^{7}$.

"Prawdziwie wielkim jest ten, kto ma wiele ducha miłości”" - tego więc ducha miłości potrzeba nam wszystkim - i wielkim, i małym, i więcej,

Szerszy kontekst przytoczonych słów:

AKTOR

Dla Sztuki tylko zawszem pragnął żyć,

lecz teraz wiem, że Sztukę z Życiem splata

nierozerwana nigdy niczym nić.

POETA

Dla Sztuki żyć, to znaczy żyć dla świata! AKTOR

to $\mathrm{z}$ rajskich kwiatów zbierać krople ros, dla ludzkich dusz, co w ziemskiej schną posuszy;

to znaczy mieć anielskiej surmy głos,

którego nawet gromów ryk nie zgłuszy!

(L. Rydel, Prolog na otwarcie teatru w Krakowie dn. 27 czerwca 1893. Sceny wierszem, w: tegoż, Utwory dramatyczne, Kraków 1902, t. 2, s. 118. Prwdr. „Czas” 1893, nr 242 i odb.).

8 Sentencja z Naśladowania Chrystusa Tomasza à Kempis, dzieła niezwykle popularnego w XIX wieku. W tłumaczeniu Anny Kamieńskiej: „Prawdziwie wielki jest ten, kto ma w sobie wielką miłość”; autor korzystał prawdopodobnie z wersji ks. Alek- 
i mniej uposażonym w geniusz i wiedzę; tym pierwszym potrzeba go jeszcze więcej niż drugim, bo oni mają prowadzić, rozjaśniać nasze drogi, ogrzewać nasze serca.

Muszą więc mieć wiele ognia w sobie, aby ten ogień przelewać w inne dusze, muszą mieć wiele wyrozumiałości, aby do tych duchów mniejszych umieć skutecznie trafić - inaczej spalą się jak meteor świetny, sobie tylko świecący, a nieogrzewający naszego ubogiego ogniska.

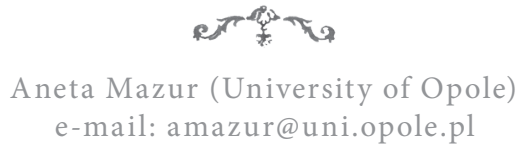

On the Trail of a Mysterious M.K.

A B S T R A C T

The article titled Artists and Philistines, published in 1897 in the "Kurier Niedzielny", a moderated weekly with a compromising orientation (publisher: Maria Chełmońska, editors: Ludomir Grendyszyński), is an example of a voice about artist-society relationship typical of the end of the century. The author takes an indirect position: he criticizes both the anti-art social climate and the artists themselves, who wrongly accuse a society solidly fulfilling its duties of being "philistine". The peculiarities of the script, the cryptic code and the ambiguous attitude of the journalist, as well as a number of clues in literary and artistic life, constitute a set of data that hypothetically propose a possible author of the text hidden under the initials "M.K". Maria Konopnicka's candidature is supported by the fact of her cooperation with the magazine and her distance from "young", anti-Nietzchean judgements. Other premises indicate a representative of the second generation of Positivists involving some of the persons closely related to the magazine, and who may have had the knowledge referred to in the article: Maria Chełmońska of Korwin-Szymanowscy, Wacław Marian Karczewski and Marian Gawalewicz. On the other hand, the clue of the initials and the author's good orientation in German-language literature would lead to lesser-known commentators, humanists or Germanists, who also represent the younger generations: Maria Feldman (publishing as Maria Kleinman and Maria Kreczowska), Maksymilian Kantecki or Michał Konopiński. The issue of authorship seems, however, to remain undecidable. None of the potential applicants meet all conditions and do not fully reflect the premises suggested by the context of different voices.

KEYWORDS

Maria Konopnicka, literary criticism, modernism, philology

sandra Jełowickiego (O naśladowaniu Jezusa Chrystusa: ksiag czworo, przeł. A. Jełowicki, Chicago 1841). 